\title{
THE LOCAL-INTERNATIONAL RELATIONSHIP: A CALL FOR AN INSTITUTIONAL APPROACH
}

"Structurally and functionally, a labor union is an institution. . . ."1 As an institution, it has characteristics peculiar to it and an identity of its own-an identity that has not been fully recognized by the courts. ${ }^{2}$ The confusion generated by this lack of recognition is manifest in cases where a local union seeks to disaffiliate from its international. The disaffiliation action creates a dispute over the legal right to the possession and use of certain assets, ostensibly owned by the local. The result in the courts has been a proliferation of confusing legal theories which have provided no clear guideline for the subsequent adjudication of similar controversies. ${ }^{3}$ If courts would seek to answer the questions posed by these cases from a basis of a common understanding of the unique institutional nature of the local-international relationship, ${ }^{4}$ strong, sure legal guidelines would emerge.

\section{The Issue in Context : Crocker v. Weit}

The nature of the dispute in disaffiliation cases is nowhere so acutely exposed as in the case of Crocker v. Weil. ${ }^{5}$ In December of 1957, the AFL-CIO, speaking through its general convention, expelled the Bakery and Confectionery Workers' International Union of America (BCW) from the AFL-CIO confederation of unions. The action was taken pursuant to hearings held before the federation's Ethical Practices Committee, which resulted in a finding that the BCW was "dominated, controlled or substantially influenced in the conduct of its affairs by corrupt influences in violation of the Constitution of the AFL-CIO." 6 On May 2, 1959,

1 United States v. White, 322 U.S. 694, 701 (1944); DeMille v. American Fed'n of Radio Artists, 31 Cal. 2d 139, 149, 187 P.2d 769, 779 (1947).

2 The call for courts to recognize the unique nature of the local-international relationship has been sounded again and again. See, e.g., Isaacson, The Local Union and the International, 3 N.Y.U. CONF. ON LABOR 493 (1950); Rose, Relation of Local Union to the International Organization, 38 VA. L. REv. 843 (1952); Summers, Union Schism in Perspective: Flexible Doctrines, Double Standards, and Projected Answers, 45 VA. L. REv. 261 (1959). For many years unions were simply grouped with all other unincorporated associations. See Chafee, The Internal Affairs of Associations Not for Profit, 43 HARv. L. Rev. 993 (1930).

3 These theories have been the subject of comment in many law reviews. Perhaps the best concise article, one in which the theories are both described and analyzed, is a student Note, Disposition of Union Assets on Disaffliation, 45 VA. L. REv. 244 (1959). note 2.

4 The clarion call for this "institutional" approach was sounded by Rose, supra

5227 Ore. 260, 361 P.2d 1014 (1961).

$6 I d$. at 266,361 P.2d at 1017 . 
Portland Local No. 364 seceded from the expelled international ${ }^{7}$ in order to affiliate with the newly created American Bakery and Confectionery Workers' Union ( $\mathrm{ABC}$ ), established by the AFL-CIO subsequent to its action expelling the $\mathrm{BCW}$. The $\mathrm{BCW}$ brought an action in equity to enjoin the local from taking with it the money and property it had accumulated prior to the secession. BCW based its action on article XIV, section 8 of the international's constitution, which said, in part, that "should a local union dissolve, secede, or have its charter revoked all its money and property should revert to the ownership of the International Union . . . . 8 The provision was held not controlling for two reasons. First, accepting the local-international relationship as basically contractual in nature, the court held that the international's affiliation with the AFL-CIO was an express promise made to the local at the time the local joined the international. Therefore, the expulsion from the AFLCIO worked a breach of this promise, and the local, as the victim of the breach, was relieved from further performance under the contract. As an alternative ground, the court held that because of the alleged corruption the international officers had violated the fiduciary duty owed to the local by the international organization, thus allowing the local to sever ties with the parent organization without incurring a penalty. ${ }^{9}$

The factual circumstances showed the court to be resting, conceptually at least, on very tenuous grounds. ${ }^{10}$ The express, mutual promise that the court alluded to was found in article 1 , section 2 of the international's constitution which states that the "aim" of the organization shall be the promotion of the social and economic welfare of all workers in the baking, confectionery and kindred industries. This statement of general policy is followed by a list of five ways in which the policy is to be carried out. Item number five on the list is: by "alliance with other labor organizations in matters of common concern toward the end of mutual protection

7 The reason for the long delay of seventeen months was the promise of the international that it would reaffiliate with the federation. Id. at 269, 361 P.2d at 1018 .

8 Id. at 263,361 P.2d at 1016.

9 Id. at 284,361 P.2d at 1025.

10 Though the conceptual grounds were weak, the decision had the backing of precedent. Some of the cases relied upon by the court were: Local 1140 v. United Elec. Workers, 232 Minn. 217, 45 N.W.2d 408 (1950) ; Bradley v. O'Hare, 11 App. Div. 2d 15, 202 N.Y.S.2d 141 (1960); Crawford v. Newman, 13 Misc. 2d 198, 175 N.Y.S.2d 903 (Sup. Ct. 1958); Alvino v. Carraccio, 400 Pa. 477, 162 A.2d 358 (1960).

The dissenting opinion in Crocker v. Weil, 227 Ore. 260, 291 n.4, 361 P.2d 1014, 1028 n.4 (1961), quoted statistics to show the overwhelming weight of the precedents. See Summers, supra note 2, at 265-68. Professor Summers' article is extremely well documented and his analysis is comprehensive. However, his scope is much broader than the one under discussion in this Comment, and his focus is on the secession phenomenon and its relevance to the problem of collective bargaining. His suggestion that more facts have to be uncovered before all the answers in the area can be arrived at is, of course, a sound one. Without quarreling with this need, the present discussion is aimed at providing an approach to a select problem within the secession framework which will provide consistency and fairness in application. Subsequent empirical research may show this approach to be inadequate; however, in the meantime, cases must be decided. 
and organization." 11 Because this language did not appear in previous editions of the constitution and also because the AFL and the CIO had recently merged, the court concluded that this section was a mandate to remain affliated. However, the language of the constitution quoted above does not support this conclusion. "Alliance" with other labor groups was but one method to be used in effectuating the general "aim" of the organization-the economic and social betterment of its members. An examination of the other listed "aims" shows how weak this reasoning was. Item 1, for example, called for "effective organizational action." Item 2 expressed the desire for "progressive improvement in living standards through the reduction of hours of labor, increased wages, decent working conditions, effective job security, etc." Item 3 offered "aid in securing and retaining employment." Item 4 pointed to the "promotion of labor unions generally" through lobbying. Reading these items one is struck by the breadth and generality of the provisions. ${ }^{12}$ No union would obligate itself to success in these aims, for they are merely the list of common aspirations that united all the smaller local unions into one larger and more powerful organization. Interchanging the words "duties" and "aims" was judicial sleight of hand. An organization does not pledge success in its every endeavor. Goals are set out to give an organization purpose and direction. Failing to reach or maintain one or the other recognized goal does not sever the bonds of the organization; rather it should have the effect of uniting the members more tightly in seeking to eliminate the cause of the failure. ${ }^{13}$

As an alternative ground for the decision, the court held that there had been a breach of the international's fiduciary duty. The sole evidence of this "breach" was the expulsion of the BCW by the AFL-CIO for alleged corruption. Nowhere did the court point to facts suggesting that

11227 Ore. at 280-81, 361 P.2d at 1024.

12 Article $1, \S 2$ of the constitution reads in full :

Sec. 2. The aim of the International Union shall be to promote the economic and social welfare of all workers in the baking, confectionery and kindred industries by (1) effective organizational action; (2) progressive improvement in living standards through the reduction of hours of labor, increased wages, decent working conditions, effective job security, establishment and expansion of retirement and welfare benefits, and the elimination of the hazards of unemployment and automation; (3) aid in securing and retaining employment; (4) promotion of the interests of labor unions generally and the Bakery and Confectionery Workers' International Union in particular through continued efforts in the State and Federal legislatures; (5) alliance with other organizations in matters of common concern towards the end of mutual protection and organization.

227 Ore. at $280-81,361 \mathrm{P} .2 \mathrm{~d}$ at 1024.

13 There is no international organization at all without the locals. "The basic unit in the trade union is the local ... It is with the local that all power and revenue originates." Isaacson, supra note 2 , at 498 . Unless trade union democracy is rendered impotent because of the laxness of the locals, see text accompanying note 96 infra, unhappy or outraged locals have the power to choose their own organizational leadership at the international convention. "[T]he convention is considered to be the highest body in the union, the ultimate institution through which the membershio expresses its control." Bromiwich, Union Constitutions 9 (1959). 
the local's funds were improperly used, or indeed, that the international was not still acting for the general benefit of its locals. Even if it were shown that some of the international officers were guilty of a breach of their fiduciary duties to the organization, it is questionable whether the court could validly conclude that the entire organization was so filled with corrupt influences that it no longer functioned as an effective labor union. Moreover, the court disregarded any consideration of procedural due process on the corruption issue, permitting a finding of a breach of fiduciary duty solely on the basis of a judgment made by the AFL-CIO. ${ }^{14}$

Before focusing upon the pertinent points raised in the dissenting opinion in Crocker v. Weil, it will be helpful to review the development of the court's treatment of the disposition of funds in disaffiliation cases. Such an historical examination may also help to show how different and remarkably fresh was the approach taken by the dissent. ${ }^{15}$

\section{The Legal Theories}

\section{A. Contract}

In Crocker $v$. Weil both the local and the international accepted the legal conclusion that the international constitution formed a contract between the local and the international. ${ }^{16}$ This contractual concept is a wellestablished starting point for consideration of the relationship existing within the union institution. ${ }^{17}$ Originally, labor unions were grouped with churches and fraternal organizations under the broad heading of "unincorporated associations." 18 The law applicable to such associations was

14 Crocker v. Weil, 227 Ore. 260, 289, 361 P.2d 1014, 1027 (1961) (dissenting opinion). The arguments relating to the ability of the international to function as an effective organization cut across the entire area. They seem particularly applicable in discussing "fiduciary duties," however, because of the surface appeal of the label, "corruption."

15 It may also help to show how the weight of precedent in the UE and BCW expulsion cases made the majority of Crocker feel secure in its decision, despite the variation in rationale from court to court. See note 10 supra and the cases cited therein.

16227 Ore. at 262, 361 P.2d at 1015.

17 See, e.g., Brown v. Hook, 79 Cal. App. 2d 781, 180 P.2d 982 (Dist. Ct. App. 1947) ; Harker v. McKissock, 7 N.J. 323, 81 A.2d 480 (1951). For a discussion of both these cases see text accompanying notes 20-24 infra (Brozen v. Hook); text accompanying notes 42-46 infra (Harker $v$. McKissock).

Many of the cases in this troubled area arose in New York, where until the decisive break in Bradley v. O'Hare, 11 App. Div. 2d 15, 202 N.Y.S.2d 141 (1960) (discussed at text accompanying notes 68-94 infra), the leading case had adopted the contractual approach. Brownfield v. Simon, 94 Misc. 720, 726, 158 N.Y. Supp. 187, 190 (Sup. Ct.), aff'd mem., 174 App. Div. 872, 159 N.Y. Supp. 1102 (1916), aff'd mem., 225 N.Y. 643,121 N.E. 858 (1919).

See the brief discussion of this "orthodox" approach in Greenberg, Disposition of Union Assets Upon Disaffiliation, 33 TEMrP. L.Q. 152, 153 (1960); Note, Disposition of Union Assets on Disaffiliation, 45 VA. L. REv. 244 (1959).

18 See Chafee, supra note 2; Note, 58 YALE L.J. 1171 (1949). 
based upon contract theories, and thus it was natural for the courts to apply the same notions to analogous problems arising within labor unions. ${ }^{19}$

A typical example of the application of contract theories to solve conflicts arising within a labor union was Brown v. Hook. ${ }^{20}$ In that case the local called a strike after the international had expressly forbidden such action. When the international began investigating the strike situation, the local seceded. The international claimed the local's assets in accordance with a constitutional provision that required forfeiture of the local's funds to the international "in case of the suspension, revocation of the charter, expulsion, lapsing, or disbanding. . . ."21 Both parties agreed that the constitution was a binding contract.22 The court proceeded on that basis, construed the word "disband" to mean withdrawal and secession, and awarded the funds to the international. ${ }^{23}$ The local in Brown $v$. Hook had been recalcitrant and a source of annoyance during wartime to both the international union and the federal government. ${ }^{24}$ The decision, then, was in keeping, not only with the contract theory, but also with what perhaps can be described as the court's natural sympathies. The sympathy of the courts, however, has occasionally been with the local, causing the courts to carve out exceptions to the general contract analysis. In State Council, United Am. Mechs. v. Emery, 25 a Pennsylvania court held that funds collected for sick and funeral benefits constituted "special" funds that fell outside the forfeiture-dissolution clause in the international constitution. In Emery, the money had already been paid out to the members and obviously the court felt constrained not to recall money already spent for sickness and funeral expenses.

Exceptions to the orthodox contract theory were rare ${ }^{28}$ until 1949, when the CIO expelled the United Electrical Workers (UE) from that

19 Note, Disposition of Union Assets on Disaffiliation, 45 VA. L. Rev. 244 n.2 (1959).

2079 Cal. App. 2d 781, 180 P.2d 982 (Dist. Ct. App. 1947).

21 Id. at 784, 180 P.2d at 984.

22 Ibid.

23 Id. at 785-94, 180 P.2d 987-90. It is interesting to note that the court cited both union and "voluntary association" cases. 983-84.

24 This is clear from the court's statement of facts. Id. at 782-83, 180 P.2d at

25219 Pa. 461, 68 Atl. 1023 (1908).

26 Mr. Greenberg seems to overstate the "popularity" of the "special fund" theory as an exception to the orthodox contract theory. Greenberg, supra note 17, at 156 . He cites only the Emery case itself, and even a cursory examination of the cases following Emery shows that the "special fund" theory was not widely recognized, and what recognition it did receive was limited to district and county court cases in Pennsylvania, or, if on the supreme court level, to "voluntary associations" of a nature quite different from a labor union. See, e.g., Grand Castle v. Oley Castle, $358 \mathrm{~Pa}$. 440, 58 A.2d 45 (1948) (The Lodge of the Knights of the Golden Eagle). Even in the "voluntary association" cases, the "special fund" theory was not totally acceptable. See Nokomis Tribe Red Men Dissolution Case, 331 Pa. 53, 200 Atl. 23 (1938) (Improved Order of Red Men of the State of Pennsylvania), where the local was held bound to its agreement to turn over the funds to the parent organization upon dissolution, even though the funds were for sick and death benefits. One can only conclude that prior to 1949, this exception, as well as any others, was rare indeed. 
federation for alleged communist activities. The UE cases signalled the end of strict contractual theories in the disaffiliation cases, with courts making subsequent decisions on the basis of their notions of trade union morality.

\section{B. The UE Cases-Frustration of Purpose; Unclean Hands}

In Clark $v$. Fitzgerald ${ }^{27}$ the court held that affiliation with the CIO was an inducing cause and a continuing reason for the local's affiliation with the international. When the international was expelled from the CIO, this worked a "frustration of purpose" ${ }^{28}$ of the basic objects contemplated by the parties when they entered into the contract; and when this "purpose" was undermined the foundation upon which the contract rested was dissolved. A majority of courts facing similar "disaffiliation for communist activities" situations followed the lead in Clark, though the legal reasoning varied considerably. ${ }^{29}$

In Fitzgerald v. Riverside Labor Hall ${ }^{30}$ the court dismissed a UE complaint by invoking the equitable doctrine of "unclean hands." The court's language is interesting: "So UE stands before this court in equity, garbed in red as CIO saw it and tries to awaken the court's conscience to claimed wrongs perpetrated against it." 31 Though this kind of approach may bare the court's real discomfort, one wonders if even "the chancellor's foot" may come down so heavily when the judgment of "unclean hands" was not made by a court, but by the CIO, and was a judgment about a situation that scarcely had anything to do with the case at bar.

27197 Misc. 355, 93 N.Y.S.2d 768 (Sup. Ct 1949).

28 Some courts have treated the "frustration of purpose" doctrine as if it were equivalent to a breach of "implied condition," despite the distinctions between the two approaches. Local 1140 v. United Elec. Workers, 232 Minn. 217, 45 N.W.2d 408 (1950); Duris v. Iozzi, 6 N.J. Super. 530, 70 A.2d 793 (Ch. 1949); Bozeman v. Fitzmaurice, 62 Ohio. L. Abs. 526, 107 N.E.2d 627 (Ct. App. 1951). However phrased, the courts seem to be saying simply that affiliation with the federation was essential to the local's affiliation with the international.

29 See, e.g., Vilella v. McGrath, 136 Conn. 645, 74 A.2d 187 (1950); Fitzgerald v. Riverside Labor Hall, 27 L.R.R.M. 2366 (N.Y. Sup. Ct. 1951) ; United Elec. Workers v. Kraft, 25 L.R.R.M. 2174 (Ohio C.P. 1949); cases cited note 26 supra.

Professor Summers amassed statistics that showed eleven out of nineteen reported cases held in favor of the seceding locals. Summers, supra note 2, at 266. Among the minority decisions Edwards v. Leopoldi, 20 N.J. Super. 43, 89 A.2d 264 (App. Div. 1952), is perhaps the most well reasoned opinion, though the court felt it had to analyze the evidence presented in the light of the "frustration of purpose" and "implied condition" doctrines. In Sesiar v. Local 901, 87 F. Supp. 447 (N.D. Ind. 1949), the court applied the constitutional provisions strictly in forbidding the local to remove its asets from the local treasury when it looked as if the UE would clamp a trusteeship on the funds. The court mentioned neither the "frustration of purpose" nor the "implied contract" theories, and did not discuss "communism" at all. Perhaps this neglect can be explained on procedural grounds (the court was merely asked by the international to enjoin the local's attempt to move the funds); nevertheless it seems clear from the opinion that the court knew what the underlying facts of the dispute were, and felt the strict application of the constitutional provisions answered the problem.

3027 L.R.R.M. 2366 (N.Y. Sup. Ct. 1951).

31 Id. at 2367. (Emphasis added.) 
Some courts found the "frustration of purpose" and the "unclean hands" analyses too tenuous to follow, 32 or else looked behind the theories to what has been adjudged the overriding reason for the decisions favoring the locals in the UE disaffiliation cases-i.e., the reluctance of courts to award funds to groups tainted by the "communist" label. ${ }^{33}$ The UE controversy so perplexed one Ohio court that it directed the funds to be held in trust until an NLRB certification election could be held, the winner to take all the monies. ${ }^{34}$ This decision is interesting in so far as it hints at broader "public policy" considerations, and looks to labor specialists for aid, ${ }^{35}$ but the approach has had no following because it simply ignored the relationship problem, the factual difficulties, and all but constituted judicial abdication. ${ }^{36}$

\section{The Autonomy Principle}

The varying rationales in the disaffiliation cases were not all generated by the UE cases. One of the most interesting and vital theories had its origin in factual circumstances of quite a different nature. International Union v. Becherer ${ }^{37}$ arose before the merger of the CIO and the AFL; there a local decided to bolt affiliation with the CIO and join the AFL. ${ }^{38}$ The international set up a trusteeship over the local's assets and sued in equity essentially to establish the legality of its action. ${ }^{39}$ The court held that "each local union is a separate and distinct voluntary association which owes its creation and continued existence to the will of its

32 See Fitzgerald v. Abramson, 89 F. Supp. 504 (S.D.N.Y. 1950); Seslar v. Local 901, 87 F. Supp. 447 (N.D. Ind. 1949); Bridgeport Brass Workers v. Smith, 136 Conn. 654, 74 A.2d 191 (1950); Nadworny v. Emery, 25 L.R.R.M. 2594 (Mass. Super. Ct. 1950); Walter Kidde \& Co. v. United Elec. Workers, 7 N.J. 528, 82 A.2d 184 (1951); United Pub. Workers v. Fennimore, 6 N.J. Super. 589, 70 A.2d 901 (Ch. 1950); United Elec. Workers v. Kwiecien, 25 L.R.R.M. 2178 (N.Y. Sup. Ct. 1949); Federation of Ins. Workers v. United Office Workers, 77 R.I. 210, 74 A.2d 446 (1950).

33 As Professor Summers has put it: "Engaging in communistic activities is not only unprotected, but the very taint may lead to outlawry..." Summers, The Laze of Union Discipline: What the Courts Do in Fact, 70 Y ALE L.J. 175, 185, 199 (1960). Other critics agree, see Greenberg, supra note 17, at 155 n.9.

In Fitzgerald v. Abramson, supra note 32, the court recognized this anti-communist sentiment, but gave it short shrift by saying: "[T] his Court is not authorized . . to apply one rule of law for Communists and another for anti-communists." Id. at 512 .

34 Huntsman v. McGovern, 56 Ohio L. Abs. 170, 91 N.E.2d 717 (C.P. 1949). But see Bozeman v. Fitzmaurice, 62 Ohio L. Abs. 526, 107 N.E.2d 627 (Ct. App. 1951).

35 One writer thought these arguments persuasive. See Greenberg, supra note 17 , at 158 .

36 The National Labor Relations Board clearly believes that the court has the function of determining property rights. Boston Mach. Works Co., 89 N.L.R.B. 59 (1950).

37142 N.J. Eq. 561, 61 A.2d 16 (Ch. 1948), aff'd, 4 N.J. Super. 456, 67 A.2d 900 (App. Div. 1949).

38 Actually it was rejoining the AFL. 142 N.J. Eq. at 563, 61 A.2d at 18-19.

39 Technically the suit charged a conspiracy among the twelve defendants (six of whom were on the local's board) to work an unlawful secession, but the case resolved itself into a conflict over the local's assets. Id. at $564-65,61 \mathrm{~A} .2 \mathrm{~d}$ at 19. 
own members . . . [The] confederation is a voluntary one and any local union is free to withdraw from the alliance." 40 The court concluded that each local union was a self-sufficient organization, capable of handling its own affairs and that the assets and property of the local belonged to the local membership and followed that membership wherever it went. This view, with its "trust fund" overtones, became known as the "autonomy principle." Subsequent cases that have used the "autonomy" rationale have not been sensitive to the fact that in Becherer there was apparently no forfeiture-dissolution clause in the international constitution. Thus the case has been improperly cited as authority for the propositon that if a local is relatively self-sufficient in its day to day business operations, it is not bound by the forfeiture-dissolution clause in the international constitution. ${ }^{41}$

Judge Brennen of the New Jersey Equity Court (now Mr. Justice Brennen of the United States Supreme Court) applied the Becherer rationale in Harker $v$. $M c K$ issock, ${ }^{42}$ a case involving a dissolution-forfeiture clause. Since the funds in dispute were contributed as a "trust fund" by the local members for their own benefit and because the local retained substantial freedom in the management of its own affairs-acted "autonomously"-Judge Brennen held that the local could disaffiliate at will and retain its property, despite the contrary constitutional language. A concurring opinion expressed grave doubts about overriding an express contractual clause. ${ }^{43}$ The authors of these two opinions made up a majority, though the concurring judge viewed the local-international relationship as one bound by contract, while Judge Brennen saw the national union simply as a "loose federation of autonomous locals," 44 bound together merely by a unilaterally revocable agreement. A dissenting opinion, arguing for a strict contractual approach, was filed. The dissenter maintained a wider view of the local-international relationship, saying that "the object of this and related provisions of the constitution of the union was to give stability to the organization . . . wherever the (international) union might extend." 45

On appeal the Supreme Court of New Jersey by a vote of four to three modified the holding. ${ }^{46}$ Allowing the local to secede, the court held that the

$40 I d$. at 567,61 A.2d at 20 .

41 It is interesting to note that the Becherer rationale was actually abandoned by the New Jersey Supreme Court in Harker v. McKissock, 7 N.J. 323, 81 A.2d 480 (1951). Still, its "autonomy" rationale has had vitality. See, e.g., Crocker v. Weil, 227 Ore. 260, 276-77, 361 P.2d 1014, 1022 (1961). Professor Summers has said that it is used primarily as a "filler in the goulash of reasons to excuse overriding the constitutional provisions." Summers, supra note 2 , at 264. 480 (1951).

4210 N.J. Super. 26, 76 A.2d 89 (App. Div. 1950), modified, 7 N.J. 323, 81 A.2d

4310 N.J. Super. at 43,76 A.2d at 97 (concurring opinion).

$44 I d$. at $32,76 \mathrm{~A} .2 \mathrm{~d}$ at 92 .

45 Id. at 43,76 A.2d at $97-98$.

46 Harker v. McKissock, 7 N.J. 323, 81 A.2d 480 (1951), modifying 10 N.J. Super. 26, 76 A.2d 89 (App. Div. 1950). 
dissolution-forfeiture clause was as enforceable as any other contractual provision, and awarded the funds to the international.

Both the Becherer and McKissock opinions deserve closer scrutiny. When a local acts as a relatively self-sufficient entity, and the funds in dispute are amassed as the result of contributions by the local membership and absent a forfeiture-dissolution clause, an award of the funds to a seceding local is, from an equitable standpoint, a most attractive solution to the problem. ${ }^{47}$ However, given the same set of facts plus the addition of a forfeiture-dissolution clause, courts tend to be caught between the opposing pressures of equitable considerations ${ }^{48}$ and strong legal principles.

The Becherer and McKissock cases are of special importance because they demonstrate the need for a general understanding of the localinternational relationship that can transcend particular factual circumstances. The two McKissock opinions show the struggle that courts undergo without such a common outlook. McKissock had none of the emotional or sensational qualities that colored the UE cases or Crocker v. Weil, with their "communist" and "corruption" stigmas. Nevertheless, ten judges on two New Jersey courts split equally on the question of which group was entitled to the local's funds upon secession. The judges also exhibited a variety of approaches to the problem, no matter how they voted. Certainly a judgment as to the nature of trade union institutions was apparent both in Becherer and in McKissock. Characterizing a local as "autonomous" as the court did in Becherer and at least some of the judges did in the two McKissock opinions, seems to imply that the local retains the kind of sovereignty that individual nations retain when they become part of the United Nations, and that like a UN member, ${ }^{49}$ a local may by simple declaration withdraw from the international body with its resources completely intact.50 Perhaps it is impossible to generalize about the relationship existing between a given local and its international. One noted authority has suggested that each relationship is sui generis. ${ }^{51}$ Whether this is true or not, courts are forced to make judgments about the relationship. The "autonomy" principle is the clearest

47 One recent case bears witness to the truth of this statement, at least insofar as results are concerned. See Local 1 v. Brown, 45 Misc. $2 d$ 109, 256 N.Y.S.2d 66 (Sup. Ct. 1965). This case is discussed at length at notes 98-111 infra and accompanying text.

48 These equitable considerations, while a reservoir to some, may dry up considerably as the fluid drips from court to court. The two $M c K i s s o c k$ opinions demonstrate this possibility quite clearly.

49 See, e.g., N.Y. Times, Jan. 22, 1965, p. 1, col. 2, p. 10, col. 3.

50 In the McKissock case the court split the issues of secession and the right to the funds. In a recent New York case, Local $1 \mathrm{v}$. Brown, 45 Misc. 2d 109, 256 N.Y.S.2d 66 (Sup. Ct. 1965), discussed at notes 98-111 infra and accompanying text, the court seemed to be using the same approach. Most courts, however, do not question the local's right to secede, though of course, they divide on the second issue. Uniless the "institutional" approach is carried to extremes, it does not seem to make much difference whether the issues are split or not. The question is merely one of penalty.

51 Isaacson, The Local and the International, 3 N.Y.U. CONF. ON LABOR 493, 515-16 (1950). 
example of the truth of that statement. Sui generis or not, the locals, by their affiliation with the international, have reciprocal obligations. ${ }^{52}$ The only way these obligations can be enforced is through the constitutional provisions of the international; for the international is the representative of all of the locals. ${ }^{53}$

\section{Organizational Considerations and the Dissent in Crocker v. WeIL}

It would have been less than natural in handling problems arising after the BCW expulsion for courts not to look to the UE cases for assistance. The first line of reasoning in the majority opinion in Crocker v. Weil (that affiliation with the AFL-CIO was an express promise going to the very foundation of the local-international relationship) ${ }^{54}$ is only subtly different from the "frustration of purpose" theme of Clark v. Fitzgerald. ${ }^{55}$ Both courts (and many others as well in both the UE and the $\mathrm{BCW}$ cases) declared the local-international tie severed because of the inglorious rupture of the relationship between the international and a national federation. ${ }^{56}$ Whatever the label, whatever the rationale, the connection between the local and the international was held to be intrinsically bound up with the connection between the international and the national federation. "Contract" was but a word to these courts; for a contractual relationship is based on the intention of the parties. Certainly an AFL-CIO button is not nearly as important to the local membership as better wages and hours, a stronger bargaining position and the advantages of unity within a similar occupational group. The theory that AFLCIO affiliation was a basic, inducing element, causing the local to join the international has little or no factual support. In the Clark case the local's constitution provided that the local shall be affiliated with "United Electrical, CIO." The court concluded from this, and other references to the use of the name CIO in the organizing campaign, that affiliation with the federation was an "indispensable element and inducement for the local union's associating with the parent body. . . ."57 This was true in the court's eyes, despite its admission that the local's only direct affiliation was with the international and not with the federation. 58 In Alvino $v$. Caraccio, ${ }^{59}$ a BCW case decided by the Supreme Court of Pennsylvania,

$52 \mathrm{~A}$ true fraternal spirit permeates most of the dealings between the international and the local. Conflict arises in a small percentage of cases. Eames, The Relationship Between International and Local Unions, 15 N.Y.U. CONF. ON LABOR 23 (1962). This incisive analysis of the local-international relationship points to secession as the archetypal conflict. Id. at 29.

53 See Isaacson, supra note 51, at 495; Pierson, The Government Of Trade

Unions, 1 IND. \& LAB. ReL. REv. 605 (1948).

54 See text accompanying note 9 supra.

55 See text accompanying notes $27-29$ supra.

56 See cases cited note 28 supra.

57197 Misc. 355, 359, 93 N.Y.S.2d 768, 773 (Sup. Ct. 1949).

58 Ibid.

59400 Pa. 477, 162 A.2d 358 (1960). 
a shockingly careless disposition was maintained on similar grounds, the court not even bothering to assert any facts evidencing the "inducing cause," but simply citing UE cases for support of the proposition that affiliation with the national federation was essential to the underlying foundation of the local-international relationship. ${ }^{60}$ It seems clear from reading the opinions in these cases that the emotional considerations surrounding "communism" and "corruption" led to rationales that are difficult to defend intelligently.

The language of Justice O'Connell dissenting in Crocker v. Weil, fully exposes this hidden nerve:

If the alliance with AFL-CIO did not materially aid the BCW organization in its bargaining efforts for increased wages and benefits, the failure to continue the alliance would not constitute a material breach of the contract. The evidence does not establish that the bargaining power of the BCW was made less effective after its expulsion from the federation. There was evidence indicating that after its expulsion BCW International obtained certain benefits for the local unions. It was not shown that the benefits would have been any greater had BCW continued as a part of the federation. ${ }^{61}$

The thrust is simply this: an international can still function as an organization whether it is nominally connected with the national federation or not.

Organizational considerations cannot be brushed aside when talking of "fiduciary duties" either. Not only was the evidence in Crocker v. Weil based on AFL-CIO findings which were hearsay ${ }^{22}$ at best; but internal political tensions may have been as important as "corruption" in explaining the ouster of the international from the AFL-CIO. The central figure in the entire BCW dispute was the international's President Cross. As Professor Summers tells us:

The hostility against President Cross . . . was not based solely on his misuse of union funds, but was in part based on his efforts to modernize the union structure and allow rationalization [sic] and mechanization of the industry. These efforts helped create an opposition faction . . . which supported the ouster of the BCW and became the core of the newly created rival. ${ }^{63}$

The dissent in Crocker $v$. Weil not only criticized incisively the majority's reasoning, but also argued compellingly for an overall view of the union as an institution:

60 Id. at 484,162 A.2d at 362.

61227 Ore. at 288,361 P.2d at 1027.

62 Id. at 289, 361 P.2d at 1027.

63 Summers, Union Schism in Perspective: Flexible Doctrines, Donble Standards, and Projected Answers, 45 VA. L. Rev. 261, 269 n.42 (1959); see Fortune, Feb. 1958, p. 211. 
I think that all members of this court fully apreciate the fact that, no matter how the union constitution before us is described, it is an instrument which must be interpreted in relation to the problems which are present in union organizations... In the analysis of that problem it is essential that we keep in mind the interrelationship of the parties and their affiliates. This case does not present a conflict between BCW International and Local No. 364. Involved here is the entire organization which, of course, includes all of its component bodies. ${ }^{64}$

This approach strikes at the heart of the difficulties evidenced in the two McKissock opinions. The local and the international do not form a loose association, bound together by thin contractual ties which remain in effect only so long as each remains the exact entity it was at contract time. Rather the local is but one of a great number of small union groups who have chosen to give up their autonomy ${ }^{65}$ for the increased bargaining strength that comes with wider affiliation. ${ }^{68}$

\section{WHAT Is A UNION? \\ A. The Fiduciary Principle and Bradley v. O'Hare}

One of the best reasoned opinions in this forfeiture-dissolution area was written by the court in Bradley v. O'Hare ${ }^{67}$ - a case which the majority in Crocker v. Weil relied on heavily. ${ }^{68}$ In 1953 the International Longshoreman's Association (ILA) was expelled from the AFL on the ground of wide-spread corruption. Local 333 of the ILA then seceded from that body, taking with it over 177,000 dollars in accumulated membership dues. The international brought suit to recover the funds, on the basis of the forfeiture-dissolution clause in the ILA constitution. The trial court dismissed the complaint, holding inter alia that the forfeiture clause was contrary to public policy and therefore void. The appellate court reversed this finding and granted a new trial. Concluding that "the entire union structure in its several layers is . . . a fiduciary one," ${ }^{\circ 2}$ the court held that the local had met its burden of going forward with evidence on the issue of corruption by the introduction of evidence pertaining to the ILA

64227 Ore. at 286, 361 P.2d at 1026. (Emphasis added.)

65 See Rose, Relation of Local Union to the International Organization, $38 \mathrm{VA}$. L. REv. 843 (1952). It is good to remember that a vast number of locals do not give up their "autonomy" at all, for they have been created by the international. See Cohn \& Lubell, Control of a Labor Union-By Whom, Over What?, 22 OHio ST. L.J. 163 (1961).

66 It has been argued that collective bargaining considerations should be of paramount concern in discussing the disaffiliation cases. Summers, Union Schism in Perspective: Flexible Doctrines, Double Standards, and Projected Answers, 45 VA. L. REv. 261 (1959).

6711 App. Div. 2d 15, 202 N.Y.S.2d 141 (1960).

68227 Ore. at 284,361 P.2d at 1025.

6911 App. Div. 2d at 28, 202 N.Y.S.2d at 154. 
expulsion, but that the ILA should have the opportunity to prove the evidence infirm. In discussing the evidentiary problem the court suggested that the proof offered must be sufficient to show "an erosion of the tradeunion character of the international." 70 In the context of the opinion's discussion of the local-international relationship, and in the wider context of the general problem under discussion, this language has immense significance; for it must be remembered that the Crocker opinion in its alternative holding overlooked any evidentiary problem by concluding that the fiduciary relationship was destroyed by the expulsion for corruption decree of the AFL-CIO. ${ }^{71}$ The dissenting opinion, in arguing for an institutional approach, touched on a basic idea suggested by the language in the Bradley opinion quoted above, namely that there is a wider area of protection needed and that the local should not be permitted to disaffiliate from the international and flout the constitutional principles governing the entire union structure (including all the other locals as well) unless the institution itself is so destroyed as an institution ${ }^{72}$ as to be rendered functionally nonexistent. While the basic idea in Bradley ("erosion of the trade-union character of the international") is strikingly similar to that which permeates the dissenting opinion in Crocker (functional nonexistence) there was a crucial difference in its application in each opinion. In Bradley the destruction of the international's trade union character was established by proof of ILA's expulsion from the AFL. ${ }^{73}$ The dissenter in the Crocker case, however, would have required evidence sufficient to "show that this organization cannot function effectively in accordance with the purposes for which it was formed." 74 The latter statement implies an examination much broader in scope than the mere proof of expulsion by the AFL-CIO. An inquiry into the international's conduct in regard to the full range of its organizational activities, i.e., its role in the collective bargaining process, as a lobbyist in state or federal legislatures or as a collector and distributor of various union funds, is required. For the court in Bradley, proof of wide-spread corruption was sufficient, a prima facie case being made by the introduction of evidence of "expulsion for corruption"

70 Id. at 34, 202 N.Y.S.2d at 159.

71 See text accompanying note 14 supra.

72 The contention is simply that both the court in Bradley and the dissenting justice in Crocker were speaking to the same condition. The Bradley court remanded the case because the evidence of corruption was not "offered to establish the broader ground suggested here, namely, erosion of the trade-union character of the international." Bradley v. O'Hare, 11 App. Div. 2d 15, 34, 202 N.Y.S.2d 141, 159 (1960).

The dissenter in Crocker went a step further: "It is . . clear that the international continued to function as the parent union for a substantial number (approximately one half) of locals which remained in the organization despite the corruption." 227 Ore. at 288,361 P.2d at 1027.

The subsequent trial in Bradley ended with these ideas receiving little or no consideration, the court merely reporting that the international failed to rebut the presumption of corruption. Bradley v. O'Hare, 27 Misc. 2d 894, 214 N.Y.S.2d 136 (Sup. Ct. 1961).

7311 App. Div. 2d at 19, 202 N.Y.S.2d at 145.

74227 Ore. at 297,361 P.2d at 1031. 
from a national federation. This should not be enough. A local wishing to prove that the trade union character of the international has been destroyed should be forced to prove functional nonexistence. Allowing "wide-spread corruption" to take the place of functional non-existence results in near blanket approval for a continuation of anti-constitutional and anti-institutional results. The Bradley court with all of its analytical brilliance failed to demonstrate the weight it accorded to institutional considerations. By allowing a prima facie case to be made on "expulsion for corruption" alone, the court opened the gates for the kind of result it actually received on retrial. The new trial court simply claimed that the international failed to rebut the prima facie case and awarded the funds to the local. ${ }^{75}$ Nowhere was it made clear just what the international had to prove to make an adequate rebuttal. It would appear that so long as a few officers of the international were guilty of pilfering union funds, this would be enough to destroy the "trade union character" of the organization in the eyes of most courts. Such a position is tantamount to allowing the expulsion for corruption evidence to rise to the level of an irrebuttable presumption of institutional destruction. A better procedure would be to require that the local show destruction of the international as a functioning organization. Proof of corruption goes only part way in proving such destruction. So long as the international carries out its obligations to its members, supporting them in strike situations, providing strength at the bargaining table, etc., the local has an obligation to the other locals within the organization to stand united with them. Bad as corruption is, the solution, even where officers of an interational are involved, is not to wreck the institution, but to eliminate the corruption. Moreover Congress has provided the means with which to accomplish this goal. The use of the tools supplied by Congress will not only alleviate the internal problems, but also may strengthen union institutions.

\section{B. Fiduciaries: Bradley and the LMRDA}

Congress entered the field of regulation of internal union affairs with the passage of the Labor Management Reporting and Disclosure Act of 1959.76 In doing so, it necessarily had to make some observations concerning the institution about which it was legislating. Under section 501 of the act all representatives of a labor organization are said to "occupy positions of trust in relation to such organizations and its members as a group." 77 The act is clear in recognizing a fiduciary obligation extending from the representatives to the organization and its members; and any union constitutional provision or by-law attempting to exculpate the officers from breaches of the responsibilities imposed by this position of trust are void as against public policy. ${ }^{78}$ Thus Bradley $v$. O'Hare, in applying the

75 Bradley v. O'Hare, 27 Misc. 2d 894, 214 N.Y.S.2d 136 (Sup. Ct. 1961).

7673 Stat. 519, 29 U.S.C. $\$ \$ 401-531$ (1964).

7773 Stat. 535, 29 U.S.C. §501(a) (1964).

78 Ibid. 
"fiduciary principle" to internal union affairs, finds strong support in congressional policy. Nevertheless, Justice Breitel, speaking for the court in Bradley, might have looked more closely at the act itself before making one crucial judgment concerning the "beneficial interests" inhering in the disputed assets. His analysis of the fiduciary nature of the local-international was accurate. ${ }^{79}$ But in concluding that the "beneficial use of the assets is in the worker members, not in the organizational entity which exists solely for their benefit," 80 he missed the mark. The court maintained that all the decisions in this area, no matter what theory they relied upon, sought merely to find this "beneficial interest," and award the funds to it. Not only is this statement untrue, ${ }^{81}$ but also shows a reversion to the kind of analysis that the Pennsylvania Supreme Court used in its 1908 decision in the Emery case. ${ }^{82}$ It is neither a question of "special funds," as in Emery, nor of "beneficial interests"; what is more, the Bradley opinion itself recognizes that it is not. The opinion spoke in detail about the efforts made by the international in assisting the local to organize, ${ }^{83}$ and the reciprocal obligations owed to each organization by the other. ${ }^{84}$ It is unfortunate that the words of Justice O'Connell, dissenting in Crocker v. Weil, were not available to the Bradley court: "The combination of all these locals under the central control and leadership of the international makes up the unity of organization which the union constitution was designed to preserve." 85 Certainly the entities exist for the benefit of the workers; but they do exist, and they exist so that all of the members can share in a stronger, more unified organization.

It was suggested above ${ }^{86}$ that Justice Breitel might have looked more closely at the LMRDA before expounding his "beneficial interest" theory. For the language of section 501 (a) is illuminating insofar as it relates the union representatives' fiduciary obligation to the "organization" and "the members as a group." 87 The entire act is replete with provisions that exemplify the institutional and even governmental nature of the union structure. One of its primary aims was the strengthening of democracy within that structure. ${ }^{88}$ Thus, it contains a bill of rights; ${ }^{89}$ regula-

7911 App. Div. $2 d$ at 28, 202 N.Y.S.2d at 154.

80 Id. at $28-29,202$ N.Y.S.2d at 154.

81 The court's statement is too broad. The UE cases produced an eleven to eight split, see note 29 supra, and at least one court felt that the expulsion of the BCW from the AFL-CIO "did not nullify or affect the contractual provisions" binding the local to the international. Roberts v. Ferguson, 131 So. 2d 323, 325 (La. Ct. App. 1961).

82 See text accompanying notes 25-26 supra.

8311 App. Div. 2d at 19, 202 N.Y.S.2d at 146.

84 Id. at 22,202 N.Y.S.2d at $148-49$.

85227 Ore. at 286, $361 \mathrm{P} .2 \mathrm{~d}$ at 1026.

86 See text accompanying note 79 sippra.

8773 Stat. 535 (1959), 29 U.S.C. §501(a) (1964).

88 See Aaron, Labor-Management Reporting and Disclosure Act of 1959, 73 HARv. L. REv. 851 (1960).

89 Labor-Management Reporting \& Disclosure Act of 1959, §\$101-05, 73 Stat. 523, 29 U.S.C. $\$ \$ 411-15$ (1964). 
tions regarding voting and tenure of office; ${ }^{90}$ strict financial reporting requirements; ${ }^{91}$ tight restrictions on the use of trusteeships; ${ }^{92}$ and criminal sanctions for those who violate these provisions. ${ }^{93}$ The Bradley opinion failed to fulfill the promise of its own logical analysis. Perhaps it failed to do so merely because courts still look at unions as rather "fragile" institutions. Fifty years ago unions may have been too "fragile" to survive internal dissension and disorder. This is no longer the case. ${ }^{94}$ With the help of laws such as the IMRDA unions should be able to regulate their internal affairs and thus survive as viable institutions without judicial interference. As Professor Cox suggests, the Government has assured union members information about their financial affairs, has guaranteed them fair elections, and has to trust that the members themselves will use their good sense to remove incompetent or dishonest officials. ${ }^{95}$ It is not suggested that the passage of the LMRDA was designed to awaken members from their natural lethargy, nor was it an attempt to prod them to rid their unions of incompetency or dishonesty. ${ }^{96}$ Rather the act simply demonstrates that the institutional approach to internal labor problems has the backing of Congress; and of more central importance to this discussion, the problems that have caused the courts so much concern in these cases have been alleviated by the new controls placed upon the union hierarchies both by reporting procedures and by the tightened restrictions of criminal sanctions aimed at those who seek to undermine union democracy. By focusing on the broader institutional character of labor organizations, courts may be less inclined to invoke new theories to award funds to seceding locals, who have put these funds up as a pledge of their fidelity to a larger institution. Certainly, if the international has so stifled effective democratic procedures within the union or has become so riddled with corrupt influences that it has become a "racket" and not a labor union, then courts must declare the institution at a factual end and allow the locals to depart with all they can keep hold of. There is really no substantial proof in either the UE or the BCW cases that the international ceased to function as a labor union. Those cases may still have been properiy decided on the basis of the equities of the moment and the lack of power in the hands of the locals to prevent abuse by the interna-

9073 Stat. 532, 29 U.S.C. $\$ \$ 481-83$ (1964).

9173 Stat. 524, 29 U.S.C. $\S \S 431-38$ (1964).

8273 Stat. 530, 29 U.S.C. $\$ \S 461-66$ (1964).

9373 Stat. 529, 29 U.S.C. $\$ 439$ (1964); $\$ 301$ (c), 301(d), 73 Stat. 530, 29 U.S.C. $\$ \$ 461$ (c), 461 (d) (1964); $\$ 303($ b), 73 Stat. 531, 29 U.S.C. $\$ 463(b)$ (1964). 94 Cox, Law and National Labor Policy 86 (1960); cf. Textile Workers v. Darlington Co., 380 U.S. 263 (1965) ; American Ship Bldg. v. NLRB, 380 U.S. 300 (1965); NLRB v. Brown, 380 U.S. 278 (1965). While not directed to internal union matters, these three recent cases seem to indicate that the Supreme Court now feels the labor union to be of sufficient strength to handle problems on its own without coddling by the courts.

95 Cox, op. cit. supra note 94 , at 89.

96 Professor Aaron suggests that one of the purposes of the act was to have the workers engage more actively in self-government. Aaron, supra note 88, at 855 . 
tional officers. With the passage of the 1959 act, the locals and their members have sufficient legal weapons to achieve their own internal reforms. In the future, courts should look to the union as an institution welded together by a constitution and by-laws, and insofar as that institution continues to exist, its self-governing apparatus should be respected and unchanged by the introduction of judicial law making. ${ }^{97}$

\section{A New Case and the NeEd for a Fresh Approach}

Recently the Amalgamated Lithographers International (ALA) voted to effect a merger with the Photo Engravers International Union. Local 1 of the ALA refused to accede to the merger plans and sought to secede from the international. Local 1 prayed for judgment in a New York state court, asking the court to declare that the plaintiff had the right to sever its connection with the ALA, and asking a further declaration to the effect that the ALA had no right, title or interest in various pension and other funds and properties, most of which were held in trust for the benefit of the local membership. ${ }^{98}$ In granting summary judgment for the local, the court held that the merger worked a "frustration of purpose" of the local's membership in ALA, maintaining that the ALA was limited both historically and by its own constitution to represent and work for the interest of lithographers alone. The court declared that this policy was frustrated by a merger with another international whose membership was not exclusively confined to lithography. It was "immaterial," the court went on to say, "whether . . . the best interests of lithographers will be promoted by the merger." 98 On the issue of the funds, it was held simply that ALA had no right, title or interest in them, as they were amassed through contributions of members of Local 1 for their exclusive benefit.

The court's analysis proceeded along these lines:

1) The constitutional provisions relied upon by ALA are totally inapplicable to the present controversy. They are silent as to the right of a local to secede or to the consequences of such a secession.

2) The local's right to secede must therefore be determined by general legal principles.

3) Because ALA had been, both historically and through express constitutional language, an organization committed to

97 See Cox, op. cit. supra note 94, at 93. The proviso attached to $\$ 303$ (a) of the act reinforces the constitutions and by-laws of these organizations giving them the binding effect of law. After providing for certain restrictions on labor unions acting under trusteeship the proviso reads: "Provided, that nothing herein shall prevent the distribution of the assets of a labor organization in accordance with its constitution and bylaws upon bona fide dissolution thereof." 73 Stat. 531, 29 U.S.C. $\S 463$ (a) (1964).

98 Local 1 v. Brown, 45 Misc. 2d 109, 256 N.Y.S.2d 66 (Sup. Ct. 1965).

99 Id. at 115,256 N.Y.S.2d at 72. 
represent and work solely for the lithographic industry, any merger with a nonlithographic union works a "frustration of the purpose" of the international, allowing any local to secede at will.

4) Whether the local was "autonomous" or not is immaterial here, where there was such a frustration of the underlying purpose of the organization.

5) The ALA has no right or title or interest in funds that were amassed solely by and for the benefit of the membership of Local 1.100

\section{A. Unarticulated Difficulties}

It is difficult to determine why the court proceeded in such a disorderly fashion. It would seem that once the constitutional provisions were held inapplicable (point 1), the rest of the considerations would be moot. This is so because the international would be bereft of a basis for argument once the constitutional provisions were construed so as not to apply. Yet the court in Local 1 v. Brown felt compelled to justify the secession on the basis of "general legal principles"; ${ }^{101}$ and did so by invoking the "frustration of purpose" doctrine. ${ }^{102}$

What if the facts of the case were altered slightly and the local had seceded because it did not like the political affiliations of the international officers, or perhaps because certain internal reforms were not acceptable to the local. The "frustration" doctrine would have dropped out of the case; but if the constitutional principles were not applicable, the result would still not have been changed. ${ }^{103}$ It is possibly dangerous to predict what the court would have done under these circumstances. Perhaps the "autonomy" principle (point 4) would then have become very important; and read together with the "trust fund" theory (point 5) the result would have been the same as in Becherer. All this talk of "frustration of purpose" or "autonomy" or "trust fund" is unnecessary, though, given the fact that the constitutional provisions do not apply. Still the court felt bound to go beyond the constitution. Why? Somehow the fact that a local chose to disrupt an organization to which it had belonged as an

100 Id. at 109,256 N.Y.S.2d at 66 . The opinion was not divided into this five point structural format; however, this outline is an abstract of how the court proceeded.

101 Id. at 113,256 N.Y.S.2d at 70.

$102 I d$. at 115,256 N.Y.S.2d at 71.

103 If the constitutional provisions are not applicable, the international would have no legal basis upon which to claim the funds. In all other cases in this area the international was able to press a trusteeship or succeed outright to the funds only on the basis of constitutional provisions. Indeed, this is the whole foundation of the original orthodox contract theory. See, e.g., the discussion of the McKissock case at text accompanying notes $43-47$ supra. The McKissock case is the prime example of a court permitting secession simply as an inherent right, yet enforcing the constitutional provisions to allow the international to obtain the funds. 
active member for so long a time must have troubled the court. This difficulty is unarticulated in the opinion. If the problem continues to be an unarticulated one, future courts will continue to apply such labels as "autonomy" or "trust fund" or "frustration" or even "contract" to gain results both unpredictable and contradictory.

\section{B. An Institutional Approach}

Local 1 was one of the founders of the Amalgamated Lithographers International and had continuously been its richest and most powerful member. Local 1 had even lent money to the parent organization. ${ }^{104}$ Yet it agreed to join forces with the international; it agreed to unite its voice and strength, in some measure at least, to the voices and strengths of the other locals who combined to make ALA. The crucial problem in such cases is determining to what extent this agreement binds each local to the international and to each other. Local 1 argued that ALA was composed of independent, self-governing locals and pointed to the history of the organization and to the constitution to demonstrate the strength of this argument. ${ }^{105}$ The court should have tried the case on the basis of these issues alone. If it is true that the locals are self-sufficient groups and their association with each other is largely one of voluntary cooperation rather than obligation, then their right to sever ties with the parent group without penalty is unquestionable. History alone does not supply an answer, though it may help in understanding the constitution; for union obligations are solemnized in the union constitution and by-laws. If the constitutional provisions have no application to the question of forfeituredissolution, then it seems impossible for a court to hold the local bound to the organization or to turn over local funds to the parent group. Being but vaguely aware of institutional considerations, courts have succeeded in confusing these questions by introducing unnecessary legal issues. Instead, courts should simply determine the extent of the binding obligations entered into by the locals who form an international, and recognize these obligations. "Frustration of purpose" language would then not be necessary; especially where the international is carrying out what has been held to be a legitimate object of any union-a merger. ${ }^{106}$ "Autonomy" language would be relevant only in determining whether or not an obligation was

104 Affidavit of Iocal 1's President Swayduck in support of the motion for summary judgment, p. 8, Local 1 v. Brown, 45 Misc. 2d 109, 256 N.Y.S.2d 66 (Sup. Ct. 1965).

105 See Memorandum in Support of Plaintiff's Motion for Summary Judgment, p. 9, Local 1 v. Brown, 45 Misc. 2d 109, 256 N.Y.S.2d 66 (Sup. Ct. 1965).

106 Merger is a legitimate object of a labor union. Musicians Local $10 \mathrm{v}$. American Fed'n of Musicians, 33 U.S.L. WEER 2188 (N.D. Ill. Sept. 30, 1965). It is also relevant that the merger here was effected as a result of the vote of a majority of locals within the international. See DeMille v. American Fed'n of Radio Artists, 31 Cal. 2d 139, 187 P.2d 769 (1947), cert. denied, 333 U.S. 876 (1948). "Mere disagreement with the majority does not absolve the dissenting minority from compliance with the action of the association taken through authorized union methods." $31 \mathrm{Cal}$. $2 \mathrm{~d}$ at 150,187 P.2d at 776. 
entered into, and not as it previously, and absurdly has been used, to allow a local to revoke a binding promise without penalty. The "autonomy" principle actually cuts the other way; for if a local is so strong and selfsufficient, there is no reason why it should not be held to its agreementsagreements that at least arguably have been forced upon small, weak or dependent locals. And "trust fund" language would be meaningless as well, for no one disputes that the money belongs, in the first instance, to those who built up the fund. But the question is whether or not those funds have been put up as a pledge of fidelity to the organization; and if such a pledge is made, then the forfeiture provision is applicable as a penalty for unfaithful action.

The court's opinion in the Brown case has been dissected, not in an effort to criticize the particular result, but merely to show how haphazard and genuinely arbitrary the approach to these cases is and shall continue to be unless and until the courts decide not to choose from a vast array of "general legal principles" one of which happens to fit a particular court's notion of trade union morality, but rather to seek a solution to an institutional problem from an institutional perspective.

Three subsidiary problems remain. A closer analysis of the governing constitutional provisions may or may not support the usual forfeituredissolution reading. This kind of issue should be triable in any of these cases, for it may happen that the agreement does not penalize the local for seceding. The absence of such a provision is hardly realistic in most cases, ${ }^{107}$ but as in Local 1 v. Brown, it may have vitality. The second item is more weighty. It revolves around the single exception this Comment advocates from the general institutional approach: that provisions should be overridden, if it is sufficiently proved that the institution can no longer function as an institution. Objection may be raised that a merger such as the one involved in the $A L A$ case does indeed undo the institution itself and attempts to create another. This issue too should be triable; but it is difficult to imagine a court holding against a merger such as this one, argued about and voted upon in a democratic proceeding by all the constituent parts of the organization. ${ }^{108}$ Alteration of the physical appearance of a union is a change, but change is necessary to the vitality and growth of any institution. ${ }^{109}$

A question also may arise as to the need for the protection of a minority from majority tyranny. There is no such thing as a bill of rights

${ }^{107}$ Local 1 argued that this particular constitution was unlike the majority of constitutions governing the local-international relationship in that it had no forfeituredissolution clause. Memorandum in Support of Plaintiff's Motion for Summary Judgment, p. 10; Affidavit of Local 1's President Swayduck in Support of the Motion for Summary Judgment, pp. 17-18, Local 1 v. Brown, 45 Misc. 2d 109, 256 N.Y.S.2d 66 (Sup. Ct. 1965).

10845 Misc. $2 d$ at 112,256 N.Y.S.2d at 69.

109 The constitution of the Amalgamated Lithographers of America has been revised and amended some seventeen times since its adoption in 1915. ALA CoNsT., Notice, p. ii. 
in the constitutions of most of the institutions under discussion. ${ }^{110}$ Logically the objection has weight; but how realistic is it? What can the majority of locals do within an international to harm one of its members unfairly, except perhaps, to adopt some overtly discriminatory measure such as an assessment plan designed to deplete a richer local's treasury for the benefit of other locals? Such extreme cases can be handled on the basis of fundamental unfairness. They are hardly likely to occur. What is more likely to occur is precisely what did happen in Local $1 \mathrm{v}$. Brownthe local will lose some power because of the broadening of the group, and the local's belief in the lack of wisdom of a merger will have to bow before the will of the majority. Union democracy is a goal long sought after. It can be maintained and improved only if the democratic spirit prevails in every sector of the union organization.

\section{Conclusion}

The UE and BCW expulsion cases resulted in a proliferation of legal theories that has left the relationship between an international and its locals to be described by each judge on the basis of his own notion of trade union morality. With the passage of the 1959 Labor Act many of the areas of judicial confusion could be obviated if union members would overcome their apathy towards the institution to which they belong and prosecute legal offenders or vote out of office those whose policies are disagreeable. Admittedly, "general propositions do not decide concrete cases." 111 But general approaches, a way of looking at a given set of facts, often do. This Comment may seem to advocate a return to the strict contractual approach of pre-1949 days. Though results which were then obtained may be quite similar in many cases, that approach is not the one urged here. Rather by looking to the local-international relationship as one of institutional and quasi-governmental ${ }^{112}$ proportions it is hoped that the courts will find more consistent guidelines in solving future cases, and perhaps as a by-product, strengthen union institutions.

110 It should be remembered, however, that Congress has provided union members with a general bill of rights. See Labor-Management Reporting \& Disclosure Act of 1959, §§ 101-05, 73 Stat. 519, 29 U.S.C. $\$ \$ 411-15$ (1965).

111 Lochner v. New York, 198 U.S. 45, 76 (1905) (Holmes, J., dissenting).

112 Professor Leo Bromwich feels the American labor movement forms a political society. BROMWICH, UNION CoNstitutions 3-4 (1959). This study, sponsored by the Fund for the Republic, encompassed some seventy international unions with a membership of nearly sixteen million. 